-Short communication

\title{
Antimicrobial and analgesic activity of leaf extracts of Phyllanthus reticulatus Poir. (Family- Euphorbiaceae)
}

\author{
Tahmina Haque, Mohammad Didare Alam Muhsin ${ }^{1}$, Taslima Akhter ${ }^{1}$, \\ Md. Emdadul Haq, Rayhana Begum and Sk. Feroz Uddin Ahmed Chowdhury ${ }^{1}$ * \\ Department of Pharmacy, Primeasia University, Banani, Dhaka-1213, Bangladesh
}

Key words: Phyllanthus reticulatus, antimicrobial and analgesic activity.

The use of plants and herbs in the treatment of diseases are almost universal in underdeveloped societies and are often more affordable than purchasing expensive modern pharmaceuticals. Most countries in the world greatly rely on traditional medicines in their primary health care where the major contribution invariably comes from medicinal plants and their preparations. Besides, a great number of modern medicines, including cardiotonic steroid, digitoxin and anticancer drugs, vincristine and vinblastine, were discovered by deliberate systematic research on medicinal plants. Thus, chemical and biological investigation of medicinal plants for the development of new and more effective therapeutic agents continued to draw the attention of scientists for a long time back. Bangladesh has a rich heritage of more than 500 medicinal plants (Yusuf et al., 1994). Many of these plants are extensively used for multifarious purposes and in diverse preparations by Ayuved-Unani and Homeopathic practitioners as well as Village Kobiraj, Street Vendors and Tribal people.

Phyllanthus reticulatus Poir. (Family- Euphorbiaceae) is a reputed medicinal plant. It grows mostly in hedges and waste places, and has been reported to be widely distributed all over Bangladesh (Ghani, 2003; Sharma \& Kumar, 2013). In traditional system of medicine, various parts of the plant has been used for curing different ailments - for instance, bark as an astringent and diuretic, leaves for antidiarrheal properties, roots in asthma and fruits for inflammation (Sharma \& Kumar, 2013). Considering the extensive uses of the plant in traditional medicine, this work was designed for a systematic biological investigation on the plant to explore if there is a scientific rationale behind its folkloric use and make an avenue towards elucidation of its active constituents. As a first step to this direction, the leaf part of the plant was selected as a primary sample and was assessed for antimicrobial and analgesic properties.

The leaves of the plant Phyllanthus reticulatus were collected from Narayanganj, Bangladesh during November 2014. Then, the plant sample was authenticated at Bangladesh National Herbarium and a voucher specimen (Accession number: 40861)

\footnotetext{
${ }^{1}$ Department of Pharmacy, Jahangirnagar University, Savar, Dhaka -1342, Bangladesh

* Corresponding author. E-mail: ferozahmed1954@yahoo.com
} 
containing the identification characteristics of the plant sample was preserved there for future reference.

The leaves were washed, sun-dried, and ground to coarse powder and then extracted by a maceration process as described earlier by Aqil et al. (2008) with some modifications. $50 \mathrm{~g}$ of the ground plant material was soaked in a mixture of $250 \mathrm{~mL}$ pure methanol and $7 \mathrm{~mL}$ distilled water with occasional shaking and stirring for 10 days. The mixture was then filtered successively through cotton plug and Whatman no. 1 filter paper. The filtrate was concentrated to dryness by evaporation over a hot water bath at $100^{\circ} \mathrm{C}$. The yield of the crude extract was $3 \mathrm{~g}$. The crude methanolic extract was then fractionated using different solvents with increasing polarities ( $n$-hexane $>$ dichloromethane $>$ methanol $>$ water) using modified Kupchan method (VanWagenen et al., 1993) and finally concentrated over hot water bath. The yields of different fractions were: Pet ether $0.75 \mathrm{~g}$, Dichloromethane $0.12 \mathrm{~g}$, and Methanol $0.55 \mathrm{~g}$ and Water $0.5 \mathrm{~g}$.

The water and methanol fractions of the crude extract were tested for antimicrobial activity against one Gram +ve bacterium, viz., Staphylococcus aureus and three Gram -ve bacteria, viz., Escherichia coli, Salmonella paratyphi and Shigella dysenteriae-12. The bacterial pathogens were supplied by the Microbiology Lab of the Department of Pharmacy, Primeasia University, Banani, Dhaka. The antimicrobial activity was studied by disc diffusion assay (Murray et al., 1995; Zavala et al., 1997) using $5 \mathrm{~mm}$ paper discs containing the antibiotic gentamicin $(10 \mu \mathrm{g} / \mathrm{disc})$ as the standard for comparison. Bacterial suspensions were streaked in agar plates with sterile cotton buds. The plates were allowed to stand for 5 minutes. Then, $5 \mathrm{~mm}$ paper discs containing $600 \mu \mathrm{g}$ each of methanol and water soluble fractions were placed in the plates. The plates were left at room temperature for $1 \mathrm{~h}$ to allow for diffusion of the extracts. The whole work was performed aseptically under Laminar Air Flow. The plates were then incubated at $37^{\circ} \mathrm{C}$ for a period of 24 hours, after which the zones of inhibition around the paper discs were measured in $\mathrm{mm}$.

The analgesic screening was performed on Swiss albino mice (approximate weight $25 \mathrm{~g}$ ). The mice were obtained from the Pharmacology Laboratory of Jahangirnagar University, Savar, Dhaka, Bangladesh. The mice were randomized into eight groups (six test groups, one control and one standard) where each group consisted of 4 mice. The Food was withdrawn 12 hours before drug administration till completion of the experiment. The animals were numbered appropriately. Three fractions (Methanol, Pet ether and Dichloromethane) of the extract were orally administered by feeding needle to the test groups at two different doses $-250 \mathrm{mg} / \mathrm{kg}$ and $500 \mathrm{mg} / \mathrm{kg}$. Control and standard groups were treated with the vehicle ( $1 \%$ Tween 80 in normal saline; $10 \mathrm{ml} / \mathrm{kg}$ ) and the standard drug Paracetamol $(40 \mathrm{mg} / \mathrm{kg})$, respectively. After 30 minutes, $0.7 \%$ acetic acid $(10 \mathrm{ml} / \mathrm{kg})$ was administered intra-peritoneally. Five minutes after the acetic acid administration, writhing were counted for 15 minutes. The average writhing was calculated by MS Excel and percentage of inhibition was determined using the following equation (Suleyman $e t$ al., 1999):

$\%$ inhibition $=(1-D / C) \times 100$

Where, $\boldsymbol{D}$ represents the number of writhes of treated groups and

$\boldsymbol{C}$ represents the number of writhes of the control group. 
The results of antimicrobial screening of the methanol and water soluble fractions of the leaf extract of the plant Phyllanthus reticulatus are tabulated as zones of inhibition in $\mathrm{mm}$ and illustrated photographically in Table 1 and Plate 1, respectively. Both the methanol and water soluble fractions showed $11 \mathrm{~mm}$ zones of inhibition against the Gram +ve bacterium, Staphylococcus aureus, while that for the standard antibiotic, gentamicin, was $16 \mathrm{~mm}$. Considering that the sample used in the investigation was a crude extract and the inhibition shown not far below that shown by the standard antibiotic, gentamicin, this activity could be considered to be strong and indicative of the presence of potent antimicrobial constituents against Grame +ve bacteria. The extracts also showed moderate activity ( 9 and $10 \mathrm{~mm}$, respectively) against the Gram -ve bacterium, Salmonella paratyphi. However, though the water soluble fraction showed a little zone of inhibition $(7 \mathrm{~mm})$ against Escherichia coli, none of the fractions showed any activity against Shigella dysenteriae-12.
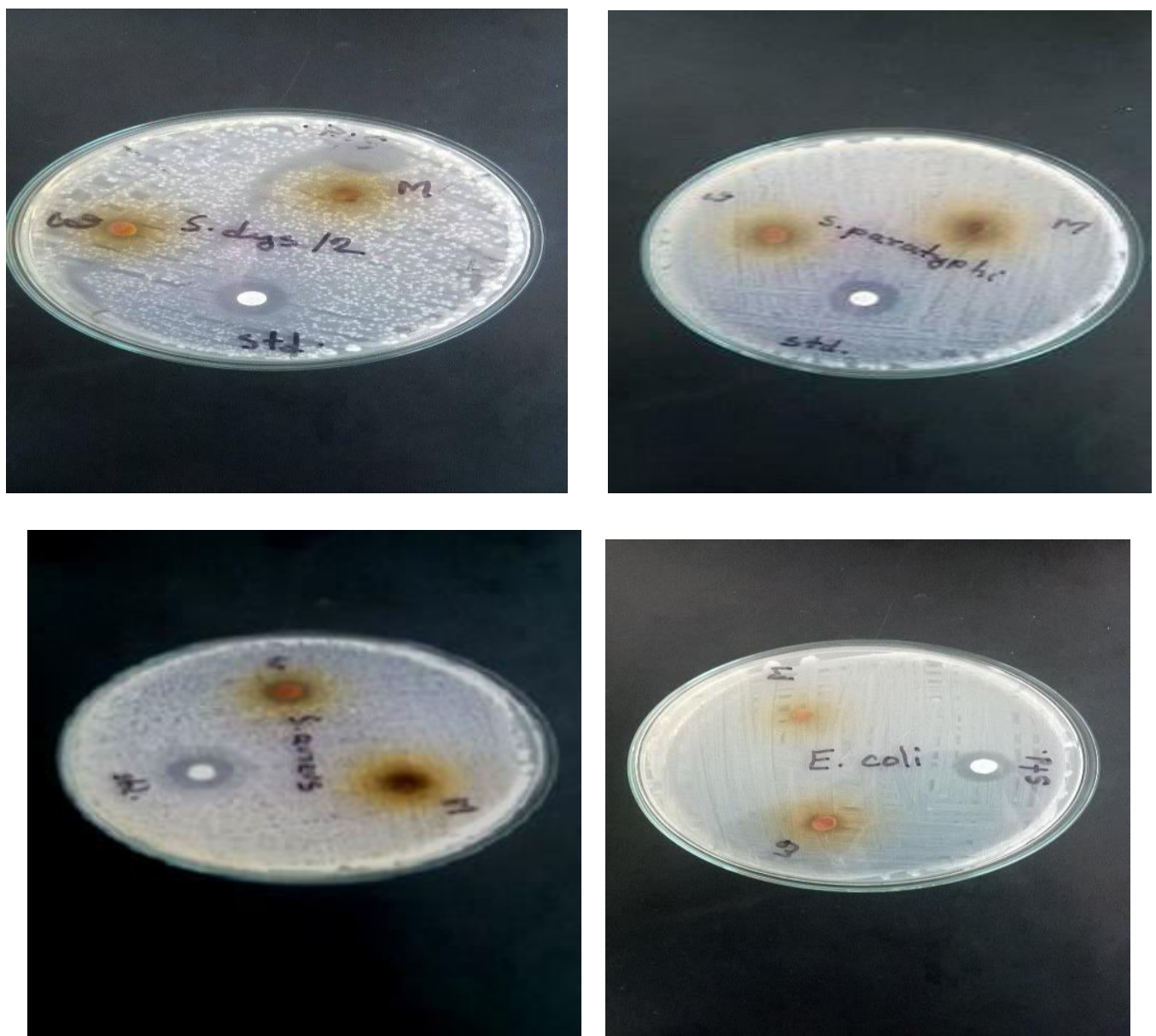

$\mathrm{M}=$ Methanol fraction, $\mathbf{W}=$ Water fraction and Std. $=$ Gentamicin

Plate 3.1. Agar plates showing the antimicrobial activity of the methanol and water fractions of the leaf extract of Phyllanthus reticulatus Poir. 
Table 1. Antimicrobial activity of $P$. reticulatus leaf extracts with methanol and water

\begin{tabular}{l|c|c|c}
\hline \multirow{2}{*}{ Name of bacteria } & \multicolumn{3}{|c}{ Zone of Inhibition (mm) } \\
\cline { 2 - 4 } & M (600ug/disc) & W (600ug/disc) & $\begin{array}{c}\text { Gentamicin } \\
\text { (10ug/disc) }\end{array}$ \\
\hline Staphylococcus aureus & 11 & 11 & 16 \\
Escherichia coli & 0 & 7 & 16 \\
Salmonella paratyphi & 9 & 10 & 16 \\
Shigella dysenteriae-12 & 0 & 0 & 15 \\
\hline
\end{tabular}

$\mathrm{M}=$ Methanol fraction, $\mathrm{W}=$ Water fraction

Table 2 shows the results of the writhing test for the investigation of analgesic activity of methanol, pet ether and dichloromethane fractions of the leaf extracts of Phyllanthus reticulatus Poir. in Swiss albino mice. In the experiment paracetamol was used as the standard drug and the percentage of inhibition of writhing exhibited by the standard drug or the extract administered were compared to the control group. Results show that, in comparison with the standard drug, paracetamol, the methanol fraction at a dose of 250 $\mathrm{mg} / \mathrm{kg}$, pet. ether fraction at $500 \mathrm{mg} / \mathrm{kg}$ and dichloromethane fraction at $500 \mathrm{mg} / \mathrm{kg} \mathrm{had}$ strong analgesic activities (74\%, 77\% and $65 \%$ of inhibition, respectively), whereas pet. ether fraction at $250 \mathrm{mg} / \mathrm{kg}$ and dichloromethane fraction at $250 \mathrm{mg} / \mathrm{kg}$ had mild analgesic activity (20\% and $26 \%$ of inhibition, respectively). These results strongly suggest that the extracts possess peripheral analgesic activity and that the mechanism of action might be mediated through inhibition of local peritoneal receptors or arachidonic acid pathways, involving cyclo-oxygenases and/ or lipoxygenases.

Table 2. Analgesic activity of methanol, pet ether and dichloromethane fractions of the leaf extract of Phyllanthus reticulatus Poir. in Swiss albino mice (in \% inhibition of writhing)

\begin{tabular}{l|c|c|c}
\hline \multicolumn{1}{c|}{ Animal group } & Dose (mg/kg) & $\begin{array}{c}\text { No. of writhing } \\
\text { (Average) }\end{array}$ & Inhibition (\%) \\
\hline Control & - & 13.50 & - \\
Standard & 40 & 2.83 & 79 \\
M & 250 & 3.50 & 74 \\
P & 250 & 10.83 & 20 \\
P & 500 & 3.17 & 77 \\
DM & 250 & 10 & 26 \\
DM & 500 & 4.66 & 65 \\
\hline
\end{tabular}

$\mathrm{M}=$ Methanol fraction, $\mathbf{P}=$ Pet ether fraction extract, $\mathrm{DM}=$ Dichloromethane

It can be concluded that the methanolic extract of the leaf part of Phyllanthus reticulatus Poir. (Family: Euphorbiaceae) has promising antimicrobial and analgesic activity. So, the leaf part of the plant might be a good prospect for the discovery of novel antimicrobials and analgesics. However, further investigations are necessary in this direction. 


\section{REFERENCE}

Aqil, F., Zahin, M. and Ahmad, I., 2008. Antimutagenic activity of methanolic extracts of four ayurvedic medicinal plants. Indian J. Exp. Biol., 46(9):668-72.

Ghani, A. 2003. Medicinal Plants of Bangladesh: Chemical Constituents and Uses. $2^{\text {nd }}$ edition. Asiatic Society of Bangladesh, Dhaka, p. 345.

Murray, P.R., Baron, E.J., Pfallar, M.A., Tenover, F.C. and Yolke, R.H., 1995. Manual of Clinical Microbiology, 6th ed, vol. 6. ASM Press, Washington DC, pp. 214-15.

Sharma, S. and Kumar, S., 2013. Phyllanthus reticulatus Poir. - An important medicinal plant: A review of its phytochemistry, traditional uses and pharmacological properties. IJPSR, 4(7): 2528-2534.

Suleyman, H., Demirezer, L.O., Kuruuzum, A., Banoglu, Z.N., Gocer, F., Ozbakir, G. and Gepdiremen A., 1999. Anti-inflammatory effect of the aqueous extract from Rumex patientia L. roots, J. Ethnopharmacol., 65(2):141-148.

VanWagenen, B.C., Larsen, R., Cardellinall, J.H., II, Randazzo, D., Lidert, Z.C. and Swithenbank, C., 1993. Ulosantoin, a potent insecticide from the sponge Ulosaruetzleri. J. Org. Chem., 58(2): 335-337.

Yusuf, M., Chowdhury, J.U., Wahab, M.A. and Begum, J. 1994. Medicinal plants of Bangladesh. Bangladesh Council of Scientific and Industrial Research, Dhaka, pp. 1-340.

Zavala, S.M.A., Perez, G.S. and Perez, G.R.M., 1997. Antimicrobial screening of some medicinal plants. Phytother. Res., 11(5):368-71. 